\title{
PENERAPAN METODE WEIGHTED PRODUCT (WP) DAN ELIMINATION ET CHOIX TRANDUISANT LA REALITÉ (ELECTRE) DENGAN PEMBOBOTAN ENTROPY MENGGUNAKAN GUI MATLAB (Studi Kasus: Pemilihan Hero Terkuat Arena of Valor)
}

\author{
Eko Adyan Sukanianto ${ }^{1}$, Sugito $^{2}$, Rita Rahmawati ${ }^{3}$ \\ 1,2,3 Departemen Statistika, Fakultas Sains dan Matematika, Universitas Diponegoro \\ e-mail : sugitostat@gmail.com
}

\begin{abstract}
Arena of Valor (AOV) is a mobile game published by Garena in Indonesia. There will be 5 players in each team, selecting a hero to play in the game. By selecting the strongest hero each role can help facilitate team to strategize the composition of heroes that will be used to achieve victory. Weighting each criteria and selecting the strongest hero also become a consideration to control the game to be stable and balanced by the developer. The alternatives are all hero from each role (Tank, Warrior, Assassin, Mage, Archer and Support), while the criterias are skill effect points, maximum HP (Health Points), physical attack, physical defense, movement speed and HP recovery every 5 seconds. In this study, the writer uses WP and ELECTRE methods to select the strongest hero with Entropy weighting method. This study produce a Matlab GUI that can be used to facilitate computational selection. The results show that the strongest hero in AOV are Grakk (Tank), Astrid (Warrior), Ormarr (Warrior), Murad (Warrior/Assassin), Lauriel (Mage/Assassin), The Joker (Archer) and Alice (Support). While the criteria with the highest weighting is the skill.
\end{abstract}

Keywords: AOV, Garena Indonesia, WP, ELECTRE, Entropy, GUI Matlab

\section{PENDAHULUAN}

Video game dapat ditemukan di berbagai perangkat elektronik yang digunakan oleh masyarakat sehari-hari seperti smartphone yang dikenal dengan nama mobile game. Di Indonesia, dunia e-sports (olahraga elektronik) mulai berkembang. Banyak pemain yang membentuk tim untuk bertanding dalam berbagai turnamen $e$-sports untuk menguji kemampuan bermain mereka. Karena kepopulerannya di Asia, e-sport dipilih masuk sebagai salah satu pertandingan Asian Games 2018 ${ }^{[8]}$ dan salah satu game yang dipertandingkan adalah AOV. Arena of Valor (AOV) adalah mobile game yang dikembangkan dan diterbitkan oleh studio Tencent.

AOV dimainkan dengan total 10 pemain yang terbagi ke dalam 2 tim. Setiap pemain diberikan kontrol kepada satu unit yang disebut Hero yang dapat mereka pilih di awal game. Dengan memilih hero terkuat dari masing-masing role dapat memudahkan tim dalam menyusun strategi komposisi hero yang akan dipakai untuk meraih kemenangan. Pembobotan masing-masing kriteria juga menjadi bahan pertimbangan oleh pihak pengembang untuk melakukan kontrol game agar stabil dan seimbang. Oleh karena itu, peneliti bermaksud untuk menentukan hero AOV terkuat sesuai dengan role-nya masingmasing dengan menggunakan metode MADM yaitu WP dan ELECTRE, dengan pembobotan menggunakan metode Entropy dan membuat GUI Matlab untuk mempermudah komputasinya.

\section{TINJAUANPUSTAKA}

\subsection{Arena of Valor (AOV)}

Arena of Valor adalah Multiplayer Online Battle Arena (MOBA) yang didesain untuk mobile devices dimana game ini dimainkan oleh total 10 pemain yang terbagi ke dalam 2 tim yaitu tim merah dan tim biru. Tujuan dari game ini adalah menghancurkan markas lawan. Sebelum dapat menghancurkan markas lawan, para pemain harus menghancurkan menara pertahanan yang berada pada 3 jalur berbeda. Setiap pemain 
diberikan kontrol kepada satu unit yang disebut hero yang dapat mereka pilih di awal game $^{[3]}$. Hero yang dapat dimainkan terbagi ke dalam 6 role (peran) yaitu Tank, Warrior, Assassin, Mage, Archer danSupport ${ }^{[1]}$.

Masing-masing hero memiliki atribut dan kemampuan ( skill) yang berbeda-beda. Daftar atribut yang dipilih dalam penelitian ini antara lain sebagai berikut:

a. Max HP (health points)

Jumlah damage yang dapat diterima oleh seorang hero. Jika HP seorang hero adalah 0 maka hero tersebut akan mati

b. Physical attack

Menambahkan damage dari serangan biasa hero dan menambah damage dari beberapakemampuan hero (biasanya kemampuan yang menimbulkan serangan fisik)

c. Physical defense (armor)

Mengurangi serangan fisik yang diterima

d. Movement speed

Menambahkan kecepatan gerakan seorang hero

e. $H P / 5 \mathrm{sec}$

Jumlah $H P$ yang dipulihkan oleh hero secara alami setiap $5 \operatorname{detik}^{[2]}$.

\subsection{Multi-Attribute Decision Making (MADM)}

Multi-Attribute Decision Making (MADM) adalah suatu metode pengambilan keputusan untuk menetapkan alternatif terbaik dari sejumlah alternatif berdasarkan kriteria tertentu $^{[7]}$. Tahapan MADM dimulai dengan membuat matriks keputusan (X) setiap alternatif terhadap setiap kriteria, $\mathbf{X}$ diberikan sebagai berikut:

$$
\mathbf{X}=\left[\begin{array}{cccc}
x_{11} & x_{12} & \cdots & x_{1 n} \\
x_{21} & x_{22} & \cdots & x_{2 n} \\
\vdots & \vdots & & \vdots \\
x_{m 1} & x_{m 2} & \cdots & x_{m n}
\end{array}\right]
$$

\subsection{Normalisasi}

Normalisasi bertujuan untuk memperoleh skala yang sebanding ${ }^{[5]}$. Ada berbagai cara menormalisasi nilai kriteria diantaranya:

a. Normalisasi Vektor

Prosedur ini menerapkan bahwa setiap vektor baris dari matriks keputusan dibagi dengan normasinya, sehingga setiap nilai hasil normalisasi $\left(r_{i j}\right)$ dapat dihitung dengan:

$$
r_{i j}=\frac{x_{i j}}{\sqrt{\sum_{i=1}^{m} x_{i j}^{2}}} ; \mathrm{i}=1,2, \ldots, \mathrm{m} ; \mathrm{j}=1,2, \ldots, \mathrm{n}
$$

b. Transformasi Skala Linear

Prosedur sederhana normalisasi ini adalah membagi hasil kriteria tertentu dengan nilai maksimumnya, sehingga hasil transformasi dari $x_{i j}$ adalah

$d_{i j}=\frac{x_{i j}}{x_{j}{ }^{*}} ;$ dengan $\mathrm{i}=1,2, \ldots$, mdan $\mathrm{j}=1,2, \ldots, \mathrm{n}$

Dengan $x_{j}^{*}=\max _{i} x_{i j}$ dan $0 \leq r_{i j} \leq 1$.

\subsection{Pembobotan Entropy}

Nilai bobot diperlukan untuk menunjukkan tingkat kepentingan relatif dari setiap kriteria.Salah satu metode yang dapat digunakan untuk memperoleh nilai bobot kriteria adalah metode Entropy.Langkah-langkahperhitungan dalam metode ini adalah sebagai berikut $^{[6]}$ : 
a. Membuat tabel alternatif-kriteria

Dengan menggunakan matriks keputusan, dapat dibentuk suatu tabel alternatifkriteria sebagai berikut:

Tabel 1. Alternatif-Kriteria

\begin{tabular}{|c|c|c|c|c|}
\hline \multirow{2}{*}{ Alternatif } & \multicolumn{4}{|c|}{ Kriteria } \\
\cline { 2 - 5 } & $C_{1}$ & $C_{2}$ & $\ldots$ & $C_{n}$ \\
\hline$A_{1}$ & $x_{11}$ & $x_{12}$ & $\ldots$ & $x_{1 \mathrm{n}}$ \\
\hline$A_{2}$ & $x_{21}$ & $x_{22}$ & $\ldots$ & $x_{2 \mathrm{n}}$ \\
\hline$\ldots$ & $\ldots$ & $\ldots$ & $\ldots$ & $\ldots$ \\
\hline$A_{m}$ & $x_{\mathrm{m} 1}$ & $x_{\mathrm{m} 2}$ & $\ldots$ & $x_{\mathrm{mn}}$ \\
\hline
\end{tabular}

b. Normalisasi tabel alternatif-kriteria

Normalisasi data nilai masing-masing alternatif $(\mathrm{i}=1,2, \ldots, \mathrm{m})$ terhadap kriteria $(\mathrm{j}=1,2, \ldots, \mathrm{n})$ diperoleh dengan rumus pada persamaan (2).Selanjutnya nilai masingmasing data yang telah dinormalisasi dijumlahkan.

$$
D_{j}=\sum_{i=1}^{m} d_{i j} ; \text { untuk semua } \mathrm{j}
$$

Dengan $d_{i j}$ adalah nilai data yang telah ternormalisasi dan $D_{j}$ adalah jumlah nilai data yang telah dinormalisasi pada setiap kriteria ke-j

c. Perhitungan Entropy

Perhitungan entropy untuk setiap kriteria ke-j diberikan sebagai berikut:

$$
e\left(d_{j}\right)=-K \sum_{i=1}^{m} \frac{d_{i j}}{D_{j}} \ln \frac{d_{i j}}{D_{j}} ; \text { untuk semua } \mathrm{j}
$$

Dengan $e\left(d_{j}\right)$ adalah nilai Entropy setiap kriteria dan $K=\frac{1}{\ln m}$

d. Perhitungan Bobot Entropy

Langkah berikutnya adalah menghitung bobot dengan menggunakan rumus sebagai berikut:

$$
\widehat{w}_{j}=\frac{1}{n-E}\left[1-e\left(d_{j}\right)\right] ; \text { dimana } \mathrm{j}=1,2, \ldots, \mathrm{n}
$$

e. Perhitungan Bobot Entropy Akhir

Jika sebelumnya telah ada bobot awal kriteria atau bobot yang telah ditentukan sebelumnya maka hasil bobot entropy akhir untuk tiap kriteria dapat dihitung dengan rumus berikut ini.

$$
w_{j}=\frac{\widehat{w}_{j} \times \alpha_{j}}{\sum_{j=1}^{n} \widehat{w}_{j} \times \alpha_{j}} \operatorname{dimana} \mathrm{j}=1,2, \ldots, \mathrm{n}
$$

Jika tidak ada bobot sebelumnya makaw $w_{j}=\widehat{w}_{j}$

Dimana: $\quad \alpha_{j}=$ bobot awal dari kriteria ke-j

$$
\widehat{w}_{j}=\text { bobot Entropy kriteria ke-j }
$$

$w_{j}=$ bobot Entropy akhir kriteria ke-j

\subsection{Weighted Product (WP)}

Metode WP menggunakan perkalian untuk menghubungkan alternatif dan kriteria, dimana alternatif setiap kriteria harus dipangkatkan dulu dengan bobot yang bersangkutan ${ }^{[10]}$. Preferensi untuk alternatif $A_{i}$ diberikan sebagai berikut:

$$
S_{i}=\prod_{j=1}^{n}\left(x_{i j}\right)^{w_{j}} ; \mathrm{i}=1,2, \ldots, \mathrm{m}
$$

Dimana $\sum_{j=1}^{n} w_{j}=1 . w_{j}$ adalah pangkat bernilai positif untuk kriteria keuntungan dan bernilai negatif untuk kriteria biaya. Preferensi relatif dari setiap alternatif, diberikan sebagai berikut:

$$
V_{i}=\frac{s_{i}}{\prod_{j=1}^{n}\left(x_{j}^{*}\right)^{w_{j}}} ; \text { dengan } \mathrm{i}=1,2, \ldots, \mathrm{m}
$$

Dimana $x_{j}^{*}$ adalah nilai maksimum dari $x_{i j}$ dan $0 \leq V_{i} \leq 1^{[11]}$. 


\subsection{Elimination Et Choix Tranduisant La Realité (ELECTRE)}

ELECTRE (Elimination Et Choix Tranduisant La Realité) didasarkan pada konsep perankingan melalui perbandingan berpasangan antar alternatif pada kriteria yang sesuai. Suatu alternatif dikatakan mendominasi alternatif lain jika satu atau lebih kriterianya melebihi (dibandingkan dengan kriteria dari alternatif lain) dan sama dengan kriteria yang lain yang tersisa. Hubungan perankingan antara 2 alternatif yangdinotasikan sebagai $A_{k}$ dan $A_{1}$, jika alternatif ke-k tidak mendominasi alternatif ke-l secara kuantitatif, lebih baik pengambil keputusan mengambil resiko $A_{k}$ daripada $A_{l}{ }^{[7]}$.

ELECTRE dimulai dari membentuk perbandingan berpasangan setiap alternatif di setiap kriteria $\left(\mathrm{x}_{\mathrm{ij}}\right)$. Nilai ini harus dinormalisasikan ke dalam suatu skala yang dapat diperbandingkan $\left(\mathrm{r}_{\mathrm{ij}}\right.$ ) membentuk matriks Rmenggunakan persamaan (1). Selanjutnya bobotdikalikan dengan matriks perbandingan berpasangan membentuk matriks $\mathbf{V}$ :

$$
v_{i j}=w_{j} r_{i j}
$$

Pembentukan concordance index dan discordance index untuk setiap pasangan alternatif dilakukan melalui taksiran terhadap relasi perankingan. himpunan corcordance index $\left\{\mathrm{c}_{\mathrm{kl}}\right\}$ menunjukkan penjumlahan bobot-bobot kriteria yang mana alternatif $\mathrm{A}_{\mathrm{k}}$ lebih baik daripada alternatif $\mathrm{A}_{1}$.

$$
\mathrm{C}_{\mathrm{kl}}=\left\{\mathrm{j} \mid v_{k j} \geq v_{l j}\right\} ; \text { untuk } \mathrm{j}=1,2, \ldots, \mathrm{n} \text { dan } k \neq l
$$

Himpunan discordance index $\left\{\mathrm{d}_{\mathrm{ij}}\right\}$ diberikan sebagai:

$$
\mathrm{D}_{\mathrm{kl}}=\left\{\mathrm{j} \mid v_{k j}<v_{l j}\right\} ; \text { untuk } \mathrm{j}=1,2, \ldots, \mathrm{n} \text { dan } k \neq l
$$

Untuk menentukan nilai dari elemen-elemen pada matriks concordance adalah dengan menjumlahkan bobot-bobot yang termasuk pada himpunan concordance, secara matematisnya adalah sebagai berikut:

$$
c_{k l}=\sum_{j \in C_{k l}} w_{j} \text { untuk } \mathrm{j}=1,2, \ldots, \mathrm{n} \text { dan } k \neq l
$$

Sehingga diperoleh matriks concordance $(\mathbf{C})$.Untuk menentukan nilai dari elemen-elemen pada matriks discordance adalah dengan membagi maksimum selisih kriteria yang termasuk ke dalam himpunan bagian discordance dengan maksimum selisih nilai seluruh kriteria yang ada, secara matematisnya adalah sebagai berikut:

$$
d_{k l}=\frac{\max \left\{\left|v_{k j}-v_{l j}\right|\right\}_{j \in D_{k l}}}{\max \left\{\left|v_{k j}-v_{l j}\right|\right\}_{\forall j}}
$$

Matriks-matriks ini dapat dibangun dengan bantuan suatu nilai ambang threshold (c).

$$
c_{k l} \geq \underline{c}
$$

dengan nilai threshold( $\underline{\mathrm{c}})$ adalah:

$$
\underline{c}=\frac{\sum_{k=1, k \neq l}^{m} \sum_{l=1, l \neq k}^{m} c_{k l}}{m(m-1)}
$$

dan elemen-elemen dari matriks concordance dominan $\mathbf{F}$ ditentukan sebagai berikut:

$$
f_{k l}= \begin{cases}1, & \text { jika } c_{k l} \geq \underline{c} \\ 0, & \text { jikac } c_{k l}<\underline{c}\end{cases}
$$

Hal yang sama juga berlaku untuk matriks discordancedominan $\mathbf{G}$ dengan threshold (d) adalah:

$$
\underline{d}=\frac{\sum_{k=1, k \neq l}^{m} \sum_{l=1, l \neq k}^{m} d_{k l}}{m(m-1)}
$$

dan elemen-elemen dari matriks discordance dominan $\mathbf{G}$ ditentukan sebagai berikut:

$$
g_{k l}= \begin{cases}1, & \text { jikad }_{k l} \geq \underline{d} \\ 0, & \text { jikad }_{k l}<\underline{d}\end{cases}
$$

Agregasi matriks dominan (E) yang menunjukkan urutan preferensi parsial dari alternatifalternatif, diperoleh dengan mengalikan setiap elemen matriks $\mathbf{F}$ dengan elemen matriks $\mathbf{G}$ yang bersesuaian, secara matematis dapat dinyatakan sebagai berikut:

$$
e_{k l}=f_{k l} \times g_{k l}
$$


Jika $e_{k l}=1$ mengindikasikan bahwa alternatif $A_{k}$ lebih dipilih daripada alternatif $\mathrm{A}_{1}{ }^{[7]}$.

\subsection{Komputasi dengan Graphic User Interfaces (GUI) dalam Matlab}

Teknik komputasi adalah cabang ilmu yang secara khusus mempelajari pelaksanaan komputer menuju pada tujuan akhir ${ }^{[9]}$. Bahasa pemrograman yang dapat digunakan bermacam-macam, salah satunya adalah Matlab. perangkat lunak Matlab adalah sistem interaktif dengan elemen dasar basis data array yang dimensinya tidak perlu dinyatakan secara khusus ${ }^{[9]}$.Graphic User Interface (GUI) merupakan Matlab script file yang dibuat untuk menunjukkan analisa suatu permasalahan khusus.Penggunaan GUI membuat program menjadi efisien, sederhana, dan familiar untuk digunakan, serta mudah untuk input data atau melihat hasilnya ${ }^{[4]}$.

\section{METODOLOGI PENELITIAN}

\subsection{Sumber Data dan Variabel Penelitian}

Data yang digunakan dalam penelitian ini merupakan data sekunder yang bersumber dari database dalam game Arena of Valor dan situs resmi Arena of Valor Indonesia. Populasi yang digunakan adalah semua hero Arena of Valor yang telah dirilis sampai dengan pembaruan 16 November 2018 yaitu sebanyak 74 hero. Sedangkan variabel yang digunakan dalam penelitian ini berupa variabel alternatif dan variabel kriteria yaitu sebagai berikut:

a. Alternatif $\left(\mathrm{A}_{\mathrm{i}}\right)$

Variabel alternatif yang digunakan dalam penelitian ini adalah hero Arena of Valor yang terbagi kedalam 6 role.

b. Kriteria $\left(\mathrm{C}_{\mathrm{j}}\right)$

Terdapat 6 variabel kriteria yang digunakan yaitu Tingkat Efek Kemampuan (Skill), Jumlah Maksimum Health Point (HP), Jumlah Serangan Fisik (Physical Attack), Jumlah Pertahanan dari Serangan Fisik (Physical Deffense), Kecepatan Pergerakan (Movement Speed) dan Jumlah Regenerasi HP setiap 5 detik

\subsection{Langkah Analisis}

Pengolahan data pada penelitian ini adalah penyeleksian hero terkuat Arena of Valor dengan menggunakan metode WP dan ELECTRE, sedangkan metode pembobotannya dengan menggunakan metode Entropy.Untuk setiap role, berikut langkahlangkah yang dilakukan untuk menganalisis data dalam penelitian ini:

a. Menyiapkan data.

b. Menghitung nilai bobot awal dengan metode Entropy.

c. Seleksi 5 hero Arena of Valor terkuat dengan menggunakan metode WP untuk setiap role

e. Menghitung bobot entropy 5 hero terpilih.

f. Menghitung bobot entropy akhir.

g. Seleksi hero terkuat Arena of Valor dengan menggunakan metode ELECTRE untuk setiap role

h. Pembuatan GUI Matlab.

\section{HASIL DAN PEMBAHASAN}

\subsection{Pembuatan Matriks Keputusan MADM (X)}

Matriks keputusan $(\mathbf{X})$ untuk masing-masing role berisi kekuatan setiap alternatif hero $\left(A_{i}\right)$ berdasarkan kriteria yang ditentukan $\left(C_{j}\right)$. Berikut ini adalah contoh matriks keputusan untuk role Tank. 
Tabel 2. Matriks Keputusan untuk Role Tank

\begin{tabular}{|c|c|c|c|c|c|c|}
\hline \multirow{2}{*}{ Hero } & \multicolumn{7}{|c|}{ Kriteria } \\
\cline { 2 - 7 } & $C_{1}$ & $C_{2}$ & $C_{3}$ & $C_{4}$ & $C_{5}$ & $C_{6}$ \\
\hline Toro $\left(A_{1}\right)$ & 3,6 & 3558 & 163 & 132 & 370 & 59 \\
\hline Gildur $\left(A_{2}\right)$ & 4,5 & 3378 & 176 & 114 & 380 & 56 \\
\hline$\vdots$ & $\vdots$ & $\vdots$ & $\vdots$ & $\vdots$ & $\vdots$ & $\vdots$ \\
\hline Y'Bneth $\left(A_{25}\right)$ & 5,5 & 3434 & 168 & 89 & 360 & 56 \\
\hline
\end{tabular}

Dimana: $C_{1}=$ Skill

$C_{4}=$ Physical Deffense

$C_{2}=$ MaxHealth Point $\quad C_{5}=$ Movement Speed

$C_{3}=$ Physical Attack $\quad C_{6}=$ Jumlah Regenerasi HP setiap 5 detik

\subsection{Perhitungan Bobot Entropy Awal}

Langkah-langkah yang digunakan untuk mencari bobot pada role Tank dalam metode ini adalah sebagai berikut:

a. Membuat tabel alternatif-kriteria

Tabel alternatif kriteria adalah tabel yang digunakan untuk mengidentifikasi hubungan antara alternatif dan kriteria. Tabel ini dapat dibentuk berdasarkan pada Tabel 2. Berikut tabel alternatif-kriteriarole Tank:

Tabel 3. Alternatif-kriteria untuk Role Tank

\begin{tabular}{|c|c|c|c|c|c|c|}
\hline \multirow{2}{*}{ Alternatif } & \multicolumn{6}{|c|}{ Kriteria } \\
\cline { 2 - 7 } & $C_{1}$ & $C_{2}$ & $C_{3}$ & $C_{4}$ & $C_{5}$ & $C_{6}$ \\
\hline$A_{1}$ & 3,6 & 3558 & 163 & 132 & 370 & 59 \\
\hline$A_{2}$ & 4,5 & 3378 & 176 & 114 & 380 & 56 \\
\hline$\vdots$ & $\vdots$ & $\vdots$ & $\vdots$ & $\vdots$ & $\vdots$ & $\vdots$ \\
\hline$A_{25}$ & 5,5 & 3434 & 168 & 89 & 360 & 56 \\
\hline Maksimum & 8,2 & 3742 & 178 & 150 & 390 & 85 \\
\hline Rata-rata & 4,868 & 3423,6 & 164,4 & 107,64 & 376 & 56,48 \\
\hline Minimum & 1,8 & 3201 & 152 & 76 & 350 & 46 \\
\hline
\end{tabular}

b. Normalisasi tabel alternatif-kriteria

Sesuai dengan persamaan (2) maka diperoleh hasil normalisasi berikut:

Tabel 4. Normalisasi Data Entropy Awal Role Tank

\begin{tabular}{|c|c|c|c|c|c|c|}
\hline \multirow{2}{*}{ Alternatif } & \multicolumn{6}{|c|}{ Kriteria } \\
\cline { 2 - 7 } & $C_{1}$ & $C_{2}$ & $C_{3}$ & $C_{4}$ & $C_{5}$ & $C_{6}$ \\
\hline$A_{1}$ & 0,4390 & 0,9508 & 0,9157 & 0,8800 & 0,9487 & 0,6941 \\
\hline$A_{2}$ & 0,5488 & 0,9027 & 0,9888 & 0,7600 & 0,9744 & 0,6588 \\
\hline$\vdots$ & $\vdots$ & $\vdots$ & $\vdots$ & $\vdots$ & $\vdots$ & $\vdots$ \\
\hline$A_{25}$ & 0,6707 & 0,9177 & 0,9438 & 0,5933 & 0,9231 & 0,6588 \\
\hline
\end{tabular}

c. Perhitungan Entropy

Menghitung nilai Entropy untuk role Tankdengan menggunakan persamaan (3)diperoleh hasil sebagai berikut:

$$
\begin{array}{lll} 
& & K=\frac{1}{\ln m}=\frac{1}{\ln (25)}=0,3107 \\
e_{1}=0,9888 & e_{3}=0,9997 & e_{5}=0,9999 \\
e_{2}=0,9998 & e_{4}=0,9963 & e_{6}=0,9979
\end{array}
$$

d. Perhitungan Bobot Entropy

Menghitung bobot Entropy dengan menggunakan persamaan (4), untuk role Tank diperoleh: 


$$
\begin{gathered}
E=\sum_{j=1}^{6} e\left(d_{j}\right)=0,9888+0,9998+\cdots+0,9979=5,9823 \\
\widehat{w}_{1}=0,6344 \quad \widehat{w}_{3}=0,0179 \quad \widehat{w}_{5}=0,0060 \\
\widehat{w}_{2}=0,0129 \quad \widehat{w}_{4}=0,2116 \quad \widehat{w}_{6}=0,1172
\end{gathered}
$$

Dengan langkah perhitungan yang sama, diperoleh nilai bobot Entropy awal setiap

\begin{tabular}{|c|c|c|c|c|c|c|c|}
\hline \multirow{2}{*}{ Role } & \multicolumn{6}{|c|}{ Bobot Kriteria } & \multirow{2}{*}{ Total } \\
\hline & $C_{1}$ & $C_{2}$ & $C_{3}$ & $C_{4}$ & $C_{5}$ & $C_{6}$ & \\
\hline Tank & 0,6344 & 0,0129 & 0,0179 & 0,2116 & 0,0060 & 0,1172 & 1 \\
\hline Warrior & 0,7205 & 0,0169 & 0,0061 & 0,0795 & 0,0040 & 0,1729 & 1 \\
\hline Assassin & 0,8759 & 0,0134 & 0,0104 & 0,0294 & 0,0128 & 0,0581 & 1 \\
\hline Mage & 0,6876 & 0,0380 & 0,0211 & 0,0783 & 0,0224 & 0,1525 & 1 \\
\hline Archer & 0,8272 & 0,0244 & 0,0288 & 0,0761 & 0,0146 & 0,0288 & 1 \\
\hline Support & 0,6457 & 0,0083 & 0,0154 & 0,1926 & 0,0100 & 0,1280 & 1 \\
\hline
\end{tabular}
kriteria pada role lainnya yang terangkum dalam tabel berikut:

Tabel 5. Nilai Bobot Entropy Awal

Pada Tabel 5 terlihat bahwa nilai bobot Entropy awal setiap kriteria pada setiap role yang tertinggi adalah bobot $\mathrm{C}_{1}$ (Tingkat Efek Kemampuan).

\subsection{Penyeleksian Awal Menggunakan Metode Weighted Product (WP)}

\begin{tabular}{|c|c|c|c|c|c|c|}
\hline \multirow{2}{*}{ Peringkat } & \multicolumn{2}{|c|}{ Tank } & \multicolumn{2}{|c|}{ Warrior } & \multicolumn{2}{|c|}{ Assassin } \\
\hline & $\overline{V_{i}}$ & Alternatif & $V_{i}$ & Alternatif & $V_{i}$ & Alternatif \\
\hline 1 & 0,8452 & $A_{19}$ & 0,8957 & $A_{16}$ & 0,9903 & $A_{13}$ \\
\hline 2 & 0,7747 & $A_{13}$ & 0,8896 & $A_{23}$ & 0,9731 & $A_{12}$ \\
\hline 3 & 0,7601 & $A_{9}$ & 0,8723 & $A_{20}$ & 0,8966 & $A_{5}$ \\
\hline 4 & 0,7358 & $A_{3}$ & 0,8436 & $A_{2}$ & 0,8159 & $A_{15}$ \\
\hline 5 & 0,7069 & $A_{23}$ & 0,8427 & $A_{13}$ & 0,8126 & $A_{6}$ \\
\hline \multirow{2}{*}{ Peringkat } & \multicolumn{2}{|c|}{ Mage } & \multicolumn{2}{|c|}{ Archer } & \multicolumn{2}{|c|}{ Support } \\
\hline & $V_{i}$ & Alternatif & $V_{i}$ & Alternatif & $V_{i}$ & Alternatif \\
\hline 1 & 0,9277 & $A_{8}$ & 0,9721 & $A_{10}$ & 0,9539 & $A_{3}$ \\
\hline 2 & 0,8958 & $A_{14}$ & 0,8261 & $A_{1}$ & 0,9272 & $A_{2}$ \\
\hline 3 & 0,8643 & $A_{9}$ & 0,8198 & $A_{5}$ & 0,8202 & $A_{4}$ \\
\hline 4 & 0,8576 & $A_{10}$ & 0,8174 & $A_{6}$ & 0,7810 & $A_{7}$ \\
\hline 5 & 0,8566 & $A_{12}$ & 0,6995 & $A_{11}$ & 0,7359 & $A_{1}$ \\
\hline
\end{tabular}

Dengan menggunakan persamaan (6) dan (7) diperoleh hasil sebagi berikut:

Tabel 6. Hasil Perankingan $V_{i}$ Metode WP

\subsection{Perhitungan Bobot Entropy Akhir}

Dengan proses yang sama seperti pembobotan Entropy awal, untuk role Tank diperoleh:

$$
\begin{array}{lll}
\widehat{w}_{1}=0,2381 & \widehat{w}_{3}=0,0337 & \widehat{w}_{5}=0,0101 \\
\widehat{w}_{2}=0,0421 & \widehat{w}_{4}=0,5262 & \widehat{w}_{6}=0,1498
\end{array}
$$

Karena ada bobot sebelumnya yaitu bobot Entropy awal (di sini disimbolkan $\alpha_{j}$ berdasarkan $w_{j}$ pada perhitungan Entropy awal) maka untuk menghitung bobot akhir $\left(w_{j}\right)$ dengan persamaan (5) untuk semua role diperoleh Tabel 7. 
Tabel 7. Nilai Bobot Entropy Akhir

\begin{tabular}{|c|c|c|c|c|c|c|c|}
\hline \multirow{2}{*}{ Role } & \multicolumn{6}{|c|}{ Bobot Kriteria } & \multirow{2}{*}{ Total } \\
\hline & $C_{1}$ & $\mathrm{C}_{2}$ & $C_{3}$ & $C_{4}$ & $C_{5}$ & $C_{6}$ & \\
\hline Tank & 0,5373 & 0,0019 & 0,0021 & 0,3959 & 0,0002 & 0,0625 & 1 \\
\hline Warrior & 0,4922 & 0,0144 & 0,0001 & 0,1240 & 0,0001 & 0,3693 & 1 \\
\hline Assassin & 0,9200 & 0,0014 & 0,0014 & 0,0130 & 0,0038 & 0,0604 & 1 \\
\hline Mage & 0,3863 & 0,0027 & 0,0021 & 0,2066 & 0,0294 & 0,3729 & 1 \\
\hline Archer & 0,9298 & 0,0021 & 0,0013 & 0,0613 & 0,0018 & 0,0038 & 1 \\
\hline Support & 0,7315 & 0,0001 & 0,0011 & 0,1879 & 0,0004 & 0,0789 & 1 \\
\hline
\end{tabular}

Pada Tabel 7 terlihat bahwa nilai bobot Entropy akhir setiap kriteria pada setiap role yang tertinggi adalah bobot $\mathrm{C}_{1}$ (Tingkat Efek Kemampuan).

\subsection{Penyeleksian Akhir Menggunakan Metode Elimination Et Choix Tranduisant La Realité (ELECTRE)}

Setelah terpilih 5 hero terkuat menggunakan metode WP, berdasarkan Tabel 2 dapat dibentuk matriks normalisasi menggunakan persamaan (1) untuk 5 heroterpilih role Tank sebagai berikut:

Tabel 8. Normalisasi Data ELECTRE 5 Hero Tank Terpilih

\begin{tabular}{|c|c|c|c|c|c|c|}
\hline \multirow{2}{*}{ Alternatif } & \multicolumn{7}{|c|}{ Kriteria } \\
\cline { 2 - 7 } & $C_{1}$ & $C_{2}$ & $C_{3}$ & $C_{4}$ & $C_{5}$ & $C_{6}$ \\
\hline TeeMee $\left(\mathrm{A}_{1}\right)$ & 0,5524 & 0,4207 & 0,4272 & 0,3707 & 0,4518 & 0,4066 \\
\hline Ormarr $\left(\mathrm{A}_{2}\right)$ & 0,4311 & 0,4534 & 0,4744 & 0,4732 & 0,4518 & 0,4647 \\
\hline Grakk $\left(\mathrm{A}_{3}\right)$ & 0,4311 & 0,4917 & 0,4383 & 0,4101 & 0,4280 & 0,5145 \\
\hline Chaugnar $\left(\mathrm{A}_{4}\right)$ & 0,3705 & 0,4351 & 0,4716 & 0,5916 & 0,4637 & 0,4564 \\
\hline Marja $\left(\mathrm{A}_{5}\right)$ & 0,4311 & 0,4317 & 0,4217 & 0,3470 & 0,4399 & 0,3817 \\
\hline
\end{tabular}

Selanjutnya menghitung matriks normalisasi terbobot untuk role Tankdengan menggunakan persamaan (8) diperoleh Tabel 9.

Tabel 9. Normalisasi Terbobot Data ELECTRE 5 Hero Tank Terpilih

\begin{tabular}{|c|c|c|c|c|c|c|}
\hline \multirow{2}{*}{ Alternatif } & \multicolumn{6}{|c|}{ Kriteria } \\
\cline { 2 - 7 } & $C_{1}$ & $C_{2}$ & $C_{3}$ & $C_{4}$ & $C_{5}$ & $C_{6}$ \\
\hline TeeMee $\left(\mathrm{A}_{1}\right)$ & 0,2968 & 0,0008 & 0,0009 & 0,1468 & 0,0001 & 0,0254 \\
\hline Ormarr $\left(\mathrm{A}_{2}\right)$ & 0,2317 & 0,0009 & 0,0010 & 0,1874 & 0,0001 & 0,0290 \\
\hline Grakk $\left(\mathrm{A}_{3}\right)$ & 0,2317 & 0,0009 & 0,0009 & 0,1624 & 0,0001 & 0,0321 \\
\hline Chaugnar $\left(\mathrm{A}_{4}\right)$ & 0,1991 & 0,0008 & 0,0010 & 0,2342 & 0,0001 & 0,0285 \\
\hline Marja $\left(\mathrm{A}_{5}\right)$ & 0,2317 & 0,0008 & 0,0009 & 0,1374 & 0,0001 & 0,0238 \\
\hline
\end{tabular}

Langkah berikutnya adalah menentukan himpunan concordance dan discordance dengan menggunakan rumus padapersamaan (9) dan (10). Setelah mendapatkan himpunan concordance dan discordance, selanjutnya menghitung matriks concordance dan discordance seperti persamaan (11) dan (12).Sehingga matriks concordance dan discordance dapat dilihat pada Tabel 10 dan Tabel 11.

Tabel 10. Matriks Concordance 5 Hero Terpilih

Role Tank

\begin{tabular}{|c|c|c|c|c|c|}
\hline $\begin{array}{c}5 \text { Hero } \\
\text { Terpilih }\end{array}$ & $A_{1}$ & $A_{2}$ & $A_{3}$ & $A_{4}$ & $A_{5}$ \\
\hline$A_{1}$ & - & 0,5375 & 0,5375 & 0,5373 & 0,9981 \\
\hline$A_{2}$ & 0,4627 & - & 0,9356 & 0,6039 & 1,0000 \\
\hline$A_{3}$ & 0,4625 & 0,6017 & - & 0,6017 & 0,9998 \\
\hline$A_{4}$ & 0,4627 & 0,3961 & 0,3983 & - & 0,4627 \\
\hline$A_{5}$ & 0,0019 & 0,5373 & 0,5375 & 0,5373 & - \\
\hline
\end{tabular}

Selanjutnya untuk menghitung matriks dominan concordance dan discordance dengan cara menghitung nilai threshold terlebih dahulu seperti pada persamaan (13) dan
Tabel 11. Matriks Discordance5 Hero Terpilih Role Tank

\begin{tabular}{|c|c|c|c|c|c|}
\hline $\begin{array}{c}5 \text { Hero } \\
\text { Terpilih }\end{array}$ & $A_{1}$ & $A_{2}$ & $A_{3}$ & $A_{4}$ & $A_{5}$ \\
\hline$A_{1}$ & - & 0,6231 & 0,2396 & 0,8947 & 0,0003 \\
\hline$A_{2}$ & 1,0000 & - & 0,1245 & 1,0000 & 0 \\
\hline$A_{3}$ & 1,0000 & 1,0000 & - & 1,0000 & 0,0001 \\
\hline$A_{4}$ & 1,0000 & 0,6955 & 0,4536 & - & 0,3365 \\
\hline$A_{5}$ & 1,0000 & 1,0000 & 1,0000 & 1,0000 & - \\
\hline
\end{tabular}

Halaman

139 
persamaan (14), sehingga matriks dominan concordance dan discordanceuntuk role Tankdapat dilihat pada tabel berikut:

Tabel 12. Matriks Dominan

Concordance5 Hero Terpilih Role Tank

\begin{tabular}{|c|c|c|c|c|c|}
\hline $\begin{array}{c}5 \text { Hero } \\
\text { Terpilih }\end{array}$ & $A_{1}$ & $A_{2}$ & $A_{3}$ & $A_{4}$ & $A_{5}$ \\
\hline$A_{1}$ & - & 0 & 0 & 0 & 1 \\
\hline$A_{2}$ & 0 & - & 1 & 1 & 1 \\
\hline$A_{3}$ & 0 & 1 & - & 1 & 1 \\
\hline$A_{4}$ & 0 & 0 & 0 & - & 0 \\
\hline$A_{5}$ & 0 & 0 & 0 & 0 & - \\
\hline
\end{tabular}

Langkah terakhir yaitu menentukan agregasi matriks dominan dengan menggunakan persamaan (15) diperoleh hasil sebagai berikut untuk semua role:

Tabel 14. Agregasi Matriks Dominan 5

Hero Terpilih Role Tank

\begin{tabular}{|c|c|c|c|c|c|c|}
\hline $\begin{array}{c}5 \text { Hero } \\
\text { Terpilih }\end{array}$ & $A_{1}$ & $A_{2}$ & $A_{3}$ & $A_{4}$ & $A_{5}$ & $\begin{array}{c}\text { Jumlah } \\
\text { Dominansi } \\
\left(e_{k l}=1\right)\end{array}$ \\
\hline$A_{1}$ & - & 0 & 0 & 0 & 0 & 0 \\
\hline$A_{2}$ & 0 & - & 0 & 1 & 0 & 1 \\
\hline$A_{3}$ & 0 & 1 & - & 1 & 0 & 2 \\
\hline$A_{4}$ & 0 & 0 & 0 & - & 0 & 0 \\
\hline$A_{5}$ & 0 & 0 & 0 & 0 & - & 0 \\
\hline
\end{tabular}

Tabel 16. Agregasi Matriks Dominan 5

Hero Terpilih Role Assassin

\begin{tabular}{|c|c|c|c|c|c|c|}
\hline $\begin{array}{c}5 \text { Hero } \\
\text { Terpilih }\end{array}$ & $A_{1}$ & $A_{2}$ & $A_{3}$ & $A_{4}$ & $A_{5}$ & $\begin{array}{c}\text { Jumlah } \\
\text { Dominansi } \\
\left(e_{k l}=1\right)\end{array}$ \\
\hline$A_{1}$ & - & 0 & 0 & 0 & 0 & 0 \\
\hline$A_{2}$ & 1 & - & 0 & 0 & 0 & 1 \\
\hline$A_{3}$ & 0 & 0 & - & 0 & 0 & 0 \\
\hline$A_{4}$ & 0 & 0 & 0 & - & 0 & 0 \\
\hline$A_{5}$ & 0 & 0 & 0 & 1 & - & 1 \\
\hline
\end{tabular}

Tabel 18. Agregasi Matriks Dominan 5

Hero Terpilih Role Archer

\begin{tabular}{|c|c|c|c|c|c|c|}
\hline $\begin{array}{c}5 \text { Hero } \\
\text { Terpilih }\end{array}$ & $A_{1}$ & $A_{2}$ & $A_{3}$ & $A_{4}$ & $A_{5}$ & $\begin{array}{c}\text { Jumlah } \\
\text { Dominansi } \\
\left(e_{k l}=1\right)\end{array}$ \\
\hline$A_{1}$ & - & 0 & 0 & 0 & 0 & 0 \\
\hline$A_{2}$ & 0 & - & 0 & 0 & 0 & 0 \\
\hline$A_{3}$ & 0 & 1 & - & 0 & 0 & 1 \\
\hline$A_{4}$ & 0 & 1 & 1 & - & 0 & 2 \\
\hline$A_{5}$ & 0 & 0 & 0 & 0 & - & 0 \\
\hline
\end{tabular}

Tabel 13. Matriks Dominan Discordance5 Hero Terpilih Role Tank

\begin{tabular}{|c|c|c|c|c|c|}
\hline $\begin{array}{c}5 \text { Hero } \\
\text { Terpilih }\end{array}$ & $A_{1}$ & $A_{2}$ & $A_{3}$ & $A_{4}$ & $A_{5}$ \\
\hline$A_{1}$ & - & 0 & 0 & 1 & 0 \\
\hline$A_{2}$ & 1 & - & 0 & 1 & 0 \\
\hline$A_{3}$ & 1 & 1 & - & 1 & 0 \\
\hline$A_{4}$ & 1 & 1 & 0 & - & 0 \\
\hline$A_{5}$ & 1 & 1 & 1 & 1 & - \\
\hline
\end{tabular}

Tabel 15. Agregasi Matriks Dominan 5 Hero Terpilih Role Warrior

\begin{tabular}{|c|c|c|c|c|c|c|}
\hline $\begin{array}{c}5 \text { Hero } \\
\text { Terpilih }\end{array}$ & $A_{1}$ & $A_{2}$ & $A_{3}$ & $A_{4}$ & $A_{5}$ & $\begin{array}{c}\text { Jumlah } \\
\text { Dominansi } \\
\left(e_{k l}=1\right)\end{array}$ \\
\hline$A_{1}$ & - & 0 & 0 & 0 & 1 & 1 \\
\hline$A_{2}$ & 0 & - & 0 & & 1 & 1 \\
\hline$A_{3}$ & 0 & 0 & - & 0 & 0 & 0 \\
\hline$A_{4}$ & 0 & 0 & 0 & - & 1 & 1 \\
\hline$A_{5}$ & 0 & 0 & 0 & 0 & - & 0 \\
\hline
\end{tabular}

Tabel 17. Agregasi Matriks Dominan 5 Hero Terpilih Role Mage

\begin{tabular}{|c|c|c|c|c|c|c|}
\hline $\begin{array}{c}5 \text { Hero } \\
\text { Terpilih }\end{array}$ & $A_{1}$ & $A_{2}$ & $A_{3}$ & $A_{4}$ & $A_{5}$ & $\begin{array}{c}\text { Jumlah } \\
\text { Dominansi } \\
\left(e_{k l}=1\right)\end{array}$ \\
\hline$A_{1}$ & - & 0 & 0 & 0 & 0 & 0 \\
\hline$A_{2}$ & 0 & - & 0 & 0 & 0 & 0 \\
\hline$A_{3}$ & 0 & 0 & - & 0 & 0 & 0 \\
\hline$A_{4}$ & 0 & 0 & 0 & - & 0 & 0 \\
\hline$A_{5}$ & 0 & 0 & 0 & 1 & - & 1 \\
\hline
\end{tabular}

Tabel 19. Agregasi Matriks Dominan 5 Hero Terpilih Role Support

\begin{tabular}{|c|c|c|c|c|c|c|}
\hline $\begin{array}{c}5 \text { Hero } \\
\text { Terpilih }\end{array}$ & $A_{1}$ & $A_{2}$ & $A_{3}$ & $A_{4}$ & $A_{5}$ & $\begin{array}{c}\text { Jumlah } \\
\text { Dominansi } \\
\left(e_{k l}=1\right)\end{array}$ \\
\hline$A_{1}$ & - & 0 & 0 & 0 & 0 & 0 \\
\hline$A_{2}$ & 1 & - & 0 & 0 & 0 & 1 \\
\hline$A_{3}$ & 0 & 0 & - & 0 & 0 & 0 \\
\hline$A_{4}$ & 0 & 0 & 1 & - & 0 & 1 \\
\hline$A_{5}$ & 0 & 0 & 1 & 1 & - & 2 \\
\hline
\end{tabular}

Dari hasil pada Tabel 14 dapat diketahui bahwa $A_{3}$ yaituhero Tank nomor 9 (Grakk) mendominasi permainan karena memiliki jumlah $e_{k l}=1$ paling banyak dibandingkan alternatif lainnya.Dari hasil pada Tabel 15 dapat diketahui bahwa $A_{1}$ hero Warrior nomor 16 (Astrid), $A_{2}$ hero Warrior nomor 23 (Murad), A4hero Warrior nomor 2 (Ormarr) masing-masing memiliki $e_{k l}=1$ sebanyak 1. Dari hasil pada Tabel 16 dapat diketahui bahwa $A_{2}$ hero Assassin nomor 12 (Lauriel) mendominasi Alhero Assassinnomor 13 (Zill) 
dan Ashero Assassin nomor 6 (Murad) mendominasi A4hero Assassin nomor 15 (Liliana).Dari hasil pada Tabel 17 dapat diketahui bahwa $A_{5}$ hero Mage nomor 12 (Lauriel) mendominasi A4hero Mage nomor 10 (Aleister). Dari hasil pada Tabel 18 dapat diketahui bahwa A4hero Archer nomor 6 (The Joker) mendominasi $A_{2}$ hero Archer nomor 1 (Violet) dan A3hero Archer nomor 5 (Fennik) serta A3hero Archer nomor 5 (Fennik) berhasil mendominasi $A_{2}$ hero Archer nomor 1 (Violet). Dari hasil pada Tabel 19 dapat diketahui bahwa $A_{2}$ hero Support nomor 2 (Payna) mendominasi $A_{l}$ hero Support nomor 3 (TeeMee), $A_{4}$ hero Support nomor 7 (Xeniel) mendominasi $A_{3}$ hero Support nomor 4 (Chaugnar) dan $A_{5}$ hero Support nomor 1 (Alice) mendominasi $A_{3}$ hero Support nomor 4 (Chaugnar) serta $A_{4}$ hero Support nomor 7 (Xeniel).

\subsection{Komputasi dan Penggunaan GUI Matlab}

Berikut ini tampilan dari GUI Matlab pemilihan hero terkuat AOV menggunakan metode WP dan ELECTREdengan pembobotan metode Entropy.

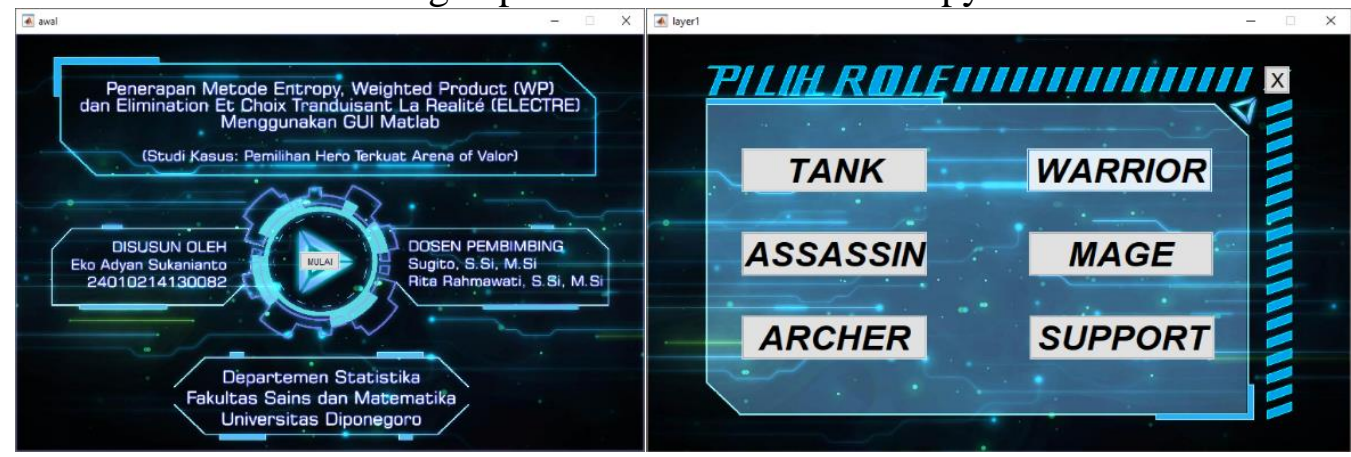

Gambar 1. Halaman Awal dan Halaman Pilih Role

Pada halaman awal, untuk memulai menggunakan program klik MULAI dan akan dialihkan ke halaman pilih role. Selanjutnya pilih role yang akan dianalisis dan akan dialihkan ke halaman hitung. Pada halaman hitung, klik Input Data dan pilih data matriks keputusan (Decision Matrix). Setelah input data, selanjtnya adalah menghitung bobot Entropy awal dengan cara klik Bobot Awal. Selanjutnya untuk mengetahui nilai preferensi relatif $\left(T_{i}\right)$ dan 5 hero terkuat pada metode Weighted Product (WP) klik Hitung WP. Selanjutnya untuk mengetahui bobot Entropy akhir dari 5 hero terpilih, klik Bobot Akhir. Setelah diperoleh bobot akhir, selanjutnya analisis metode ELECTRE dengan klik Hitung ELECTRE. Berikut tampilan hasil perhitungan untuk role Tank.

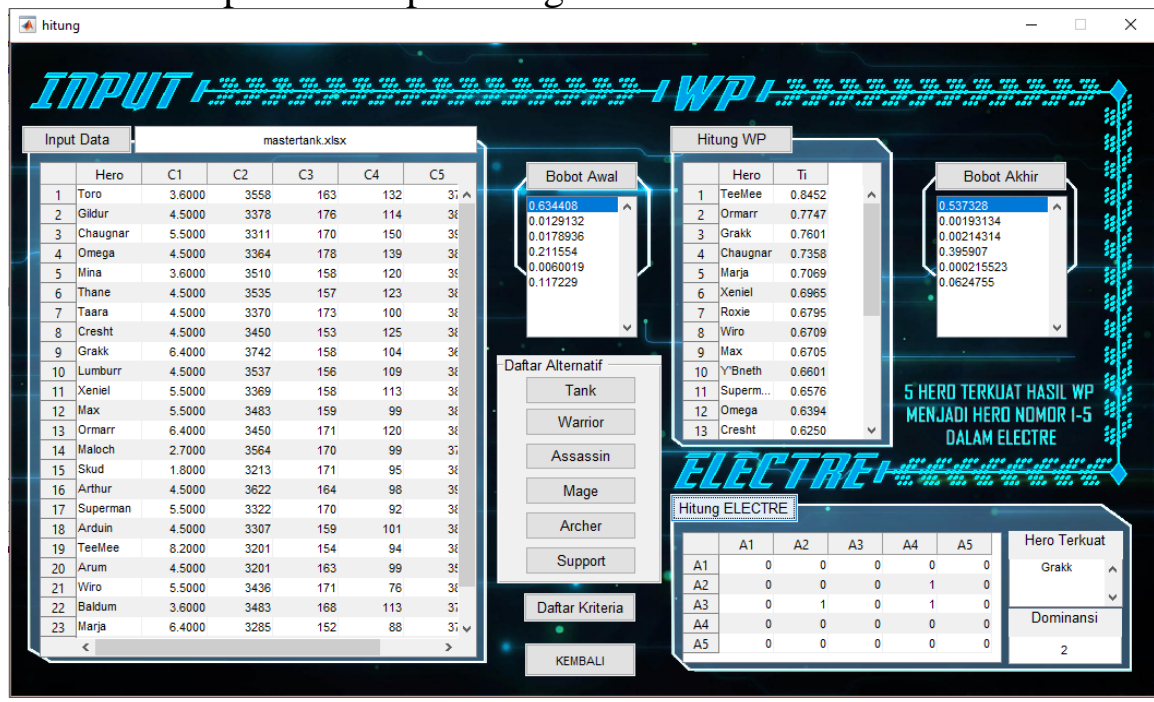

Gambar 2. Tampilan perhitungan untuk Role Tank pada Haman Hitung 


\section{KESIMPULAN}

Berdasarkan hasil dan pembahasan yang telah dilakukan, dapat diambil beberapa kesimpulan yaitu:

a. Pada perhitungan bobot Entropy baik di awal maupun di akhir, kriteria 1 (efek kemampuan) selalu mendapatkan bobot tertinggi. Hal ini berarti bahwa kriteria efek kemampuan ( $s k i l l)$ memiliki pengaruh paling besar untuk menentukan hero terkuat masing-masing role.

b. Perhitungan manual dan komputasi menggunakan GUI Matlab metode WP dan ELECTRE berhasil memilih hero terkuat pada masing-masing role dengan kriteria efek kemampuan dan beberapa atribut dasar hero. Hero terkuat untuk role Tank adalah Grakk, hero terkuat untuk role Mage adalah Lauriel, hero terkuat untuk role Archer adalah The Joker dan hero terkuat untuk role Support adalah Alice. Dalam role Warrior, hero Astrid, Murad dan Ormarr memiliki kekuatan yang seimbang. Sedangkan untuk roleAssassin, Lauriel dan Murad memiliki kekuatan yang seimbang.

\section{DAFTAR PUSTAKA}

Arena of Valor Garena Indonesia. 2017. "Cara Bermain". https://aov.garena.co. id/main/game/locate (diakses tanggal 7 Desember 2018).

Arena of Valor Proxima Beta. 2017. "New Player FAQs - 9/25/2017". https://www.arenaofvalor.com/webplat/info/news_version3/26190/26191/26192/271 94/m16480/201710/643508.shtml (diakses tanggal 7 Desember 2018).

Arena of Valor Proxima Beta. 2018. "What is Arena of Valor". https://www.arenaofvalor.com/webplat/info/news_version3/26190/33375/33740/337 43/m19427/201801/680175.shtml (diakses tanggal 7 Desember 2018).

Arhami, M. dan Desiani, A. 2005. Pemrograman Matlab. Yogyakarta: ANDI.

Hwang, C. L. dan Yoon, K. 1981. Multiple Attribute Decision Making Methods and ApplicationsA State of the Art Survey. New York: Springer Verlag.

Jamila dan Hartati, S. 2011. "Sistem Pendukung Keputusan Pemilihan Subkontrak Menggunakan Metode Entropy dan TOPSIS." IJCCS. Vol. 5 (2), 12-19

Kusumadewi, S., Hartati, S., Harjoko, A., dan Wardoyo, R. 2006. Fuzzy Multi-Atribute Decision Making (FUZZY MADM). Yogyakarta: Graha Ilmu.

Kuncorojati, C. 2018. "AOV Masuk Cabang Asian Games 2018?".http://teknologi.metrotvnews.com/game/DkqL3rWb-aov-masuk-cabangasian-games-2018 (diakses tanggal 7 Desember 2018).

Pujiyanta, A. 2007. Komputasi Numerik dengan Matlab. Yogyakarta: Graha Ilmu.

Yoon, K. 1989. "The Propagation of Errors in Multiple-attribute Decision Analysis: A Practical Approach.” Operasional Research Society. Vol. 40 (7), 681-686.

Yeh, Chun-Hsing. 2002. "A Problem-Based Selection Of Multi-Attribute Decision-Making Methods." International Federation of Operational Research Societies, pp. 169-181. 